\title{
Prostate Cancer Antigen 3 mRNA Measurement
}

National Cancer Institute

\section{Source}

National Cancer Institute. Prostate Cancer Antigen 3 mRNA Measurement. NCI

Thesaurus. Code C132379.

The determination of the amount of prostate cancer antigen 3 mRNA in a biological sample. 